\title{
Formation of a labor activity incentive system for workers in a transport company
}

\author{
A.V. Kopytova ${ }^{1 *}$, N.S. Zotkina ${ }^{1}$, and I.G. Reshetnikova ${ }^{1}$ \\ ${ }^{1}$ Tyumen Industrial University, Volodarskogo str., 38, Tyumen, 625000, Russia
}

\begin{abstract}
The article presents the author's algorithm for the formation of a rational incentive system consisting of eight stages. Its use allows the transport company to form a rational incentive system that focuses on a specific of the company, but is built on the universal algorithm, which allows taking into account the conditions of both external and internal environment.
\end{abstract}

\section{Introduction}

The age of the company, the sphere where it functions, the level of education and culture of managers and staff, working conditions, the availability and amount of budgetary funds can influence the qualitative aspect of functioning of the chosen incentive system. It is customary to distinguish different stages of the life cycle of an enterprise, which can influence the goals, methods and tools of conducting economic or other activities, the forms and systems of remuneration used and the stimulation of labor activity of the personnel.

\section{Methods and Results}

The author considers as the important condition for the viability of the RIS (rational incentive system) not only the formation of the incentive system itself (rational for a particular enterprise) but also the process of developing the RIS.

The proposed algorithm consists of eight steps and is represented in Figure 1. The algorithm provides for 8 steps, each step involves separate activities.

1. Evaluating the current system. The first stage is focused on the evaluation of the current incentive system in the enterprise. It is important to understand whether there is a need to change the working system. In order to do this, one should make an analysis of the positive and negative aspects of the current system, the state of the regulatory framework on wages and incentives for employees; there is also need to assess the motivational mood of the staff, the compliance of the functioning incentive system with the goals set for it and the enterprise. Analysis of the regulatory framework implies the compilation of a list of documents in force at the enterprise, the systematization of these documents in the targeted areas (reasons for the introduction of these regulatory documents, what they regulate and how).

* Corresponding author: a.copytowa@yandex.ru 
An employee's motivational mood can be assessed by interview methods, for example, by questionnaires of personnel.

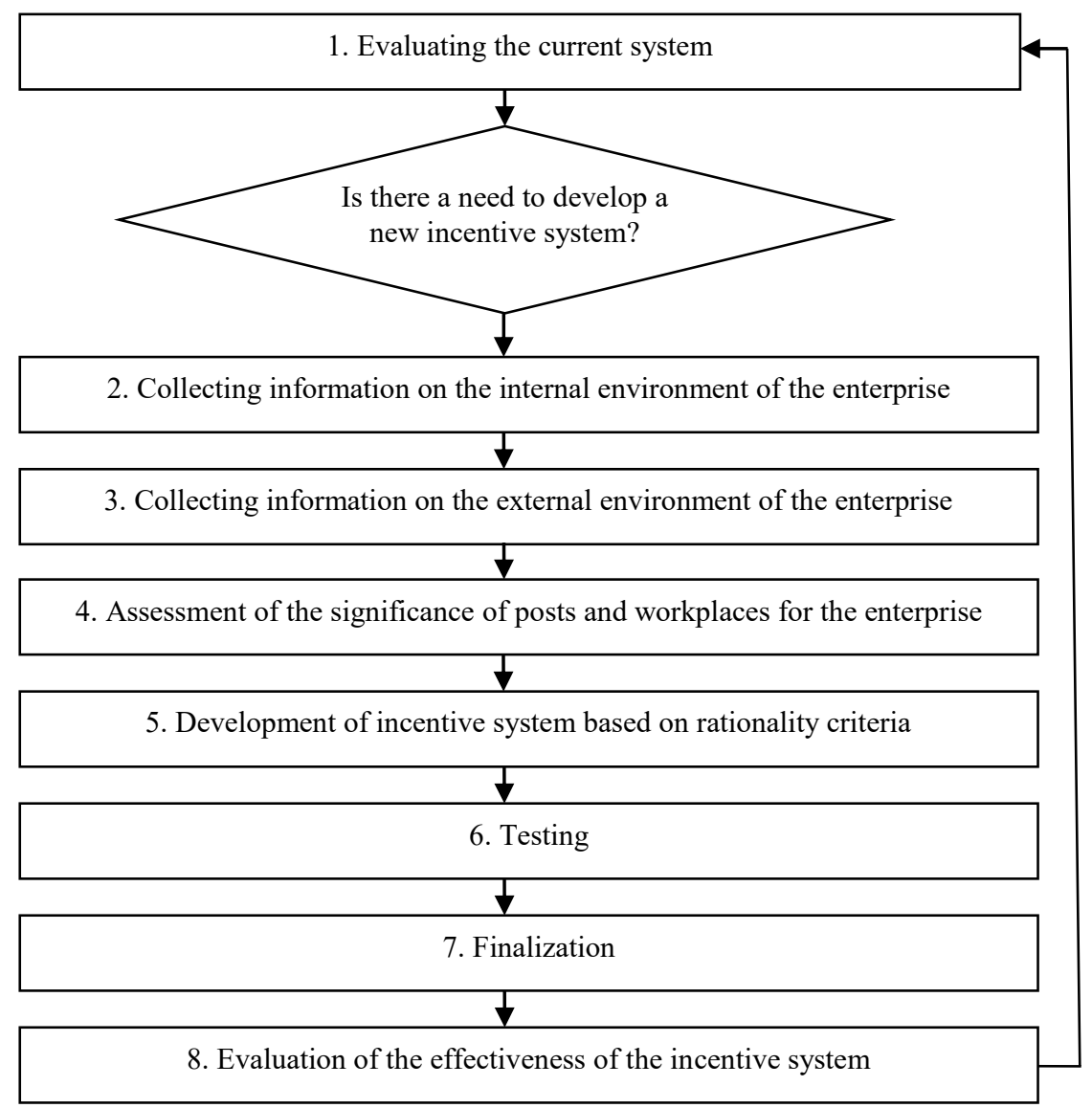

Fig. 1. Algorithm for the formation of a rational incentive system for the enterprise

The correspondence of the functioning incentive system to the goals set for it and the enterprise can be identified by resorting to the matrix presented in Table 1. The matrix gives an idea of the positive and negative trends of the functioning incentive system in relation to tasks and objectives classified by period of action.

Table 1. Matrix of correlating the objectives of the enterprise and the current incentive system (IS)

\begin{tabular}{|l|l|l|l|l|}
\hline Objectives of the enterprise & $\begin{array}{c}\text { Tasks of the } \\
\text { enterprise }\end{array}$ & $\begin{array}{c}\text { Objectives of } \\
\text { the current IS }\end{array}$ & $\begin{array}{c}\text { Positive aspects of } \\
\text { the current IS }\end{array}$ & $\begin{array}{c}\text { Negative aspects } \\
\text { of the current IS }\end{array}$ \\
\hline Short-term & & & & \\
\hline Medium-term & & & & \\
\hline Long-term & & & & \\
\hline
\end{tabular}

Goals are determined by the constituent documents of the enterprise. Depending on the objectives of the company, there are certain rules for payment and incentives for staff. At the same time, the current incentive system has certain explicit or latent goals. Table 2 presents examples of the company's objectives, the objectives of the current incentive system and the positive / negative aspects of the current incentive system. 
Table 2. Example of formulations for filling the matrix of correlating the company's objectives and the current incentive system (Table 1)

\begin{tabular}{|c|c|}
\hline $\begin{array}{l}\text { The objectives and } \\
\text { characteristics of the } \\
\text { incentive system }\end{array}$ & Indicators \\
\hline $\begin{array}{l}\text { Long-term and medium- } \\
\text { term objectives of the } \\
\text { company }\end{array}$ & $\begin{array}{l}\text { - profit making; } \\
\text { - improving the living standards of the owners of the } \\
\text { enterprise and members of the work collective; } \\
\text { - creation of a competitive enterprise in a certain market; } \\
\text { - providing the population with quality goods, jobs, services, } \\
\text { etc. }\end{array}$ \\
\hline $\begin{array}{l}\text { Medium-term and short- } \\
\text { term objectives of the } \\
\text { enterprise }\end{array}$ & $\begin{array}{ll} & \text { increase in sales; } \\
\text { - } & \text { increase in production; } \\
\text { - } & \text { training and retraining of personnel; } \\
\text { - } & \text { selection of qualified specialists; } \\
\text { - } & \text { development of new types of production; } \\
\text { - } & \text { optimization of the assortment list; } \\
\text { - } & \text { increase in loyal consumers; } \\
\text { - } & \text { work on recognizing the brand, etc. }\end{array}$ \\
\hline $\begin{array}{l}\text { The objectives of the } \\
\text { current incentive system, } \\
\text { its characteristics: }\end{array}$ & $\begin{array}{l}\text { - } \text { compliance with applicable law; } \\
\text { - } \text { providing enterprise workforce; } \\
\text { - } \text { creation of an active labor atmosphere; } \\
\text { - } \text { ensuring the development of employees of the organization; } \\
\text { - } \text { material enrichment of the staff of the governing levels and } \\
\text { founders, etc. }\end{array}$ \\
\hline $\begin{array}{l}\text {-Positive aspects of the } \\
\text { current incentive system }\end{array}$ & $\begin{array}{l}\text { - compliance with applicable law; } \\
\text { - creating a friendly atmosphere in the team; } \\
\text { - development of personnel in a professional manner (increase } \\
\text { in the number of employees with education or advanced } \\
\text { qualifications); } \\
\text { - Increasing the cultural level of the staff by providing tickets } \\
\text { to the theater, to exhibitions, cinema, a museum, etc. } \\
\text { - provision of material assistance; } \\
\text { - low level of turnover of administrative personnel, etc. }\end{array}$ \\
\hline $\begin{array}{l}\text {-Negative aspects of the } \\
\text { current incentive system }\end{array}$ & $\begin{array}{l}\text { - low level of initiative proposals from the staff; } \\
\text { - failure to meet the sales plan due to inadequate staff activity; } \\
\text { — failure to meet the production plan due to the "human } \\
\text { factor"; } \\
\text { - turnover of staff, etc. }\end{array}$ \\
\hline
\end{tabular}

If the answer to the question "Is there a need to develop a new incentive system?" is positive for the management of the organization after evaluating the current incentive system, it makes sense to proceed to the next stage, gathering information on the company's internal environment. If it turns out that the current system meets the requirements and goals of the organization, then it is possible that it should be delayed with innovations. Refusal of changes in the current system may be the most correct decision. Before proceeding to the development of a new one, it is necessary to clearly understand what requirements the already functioning system does not match. Innovations are always a difficult way, it will necessarily contain a number of risks, which are unacceptable to underestimate. Thus, the refusal to change the current incentive system is an acceptable solution. 
2. Collection of information on the internal environment of the enterprise occurs according to a previously approved list of indicators. A variant of the form for recording the results of information on the internal environment of the enterprise is presented in Table 3

Table 3. Information on the internal environment

\begin{tabular}{|c|c|}
\hline indicator & $\begin{array}{l}\text { Characteristics of the indicator in the } \\
\text { enterprise under study }\end{array}$ \\
\hline Term of existence of the enterprise & Number of years \\
\hline Number of staff & Total number of employees \\
\hline Staff structure & Leaders, specialists, workers \\
\hline Activities approved by the constituent documents & List of activities \\
\hline Actual Activities & List of activities \\
\hline Average salary of the enterprise & In rubles \\
\hline $\begin{array}{l}\text { Dynamics of average wages at the enterprise for the last 3-5 } \\
\text { years }\end{array}$ & In rubles \\
\hline Wage range & $\begin{array}{l}\text { Specify the minimum and maximum wages in } \\
\text { rubles }\end{array}$ \\
\hline $\begin{array}{l}\text { The average salary for the categories allocated by the } \\
\text { enterprise }\end{array}$ & In rubles \\
\hline List of positions with minimum wages & specific profession \\
\hline Minimum wage range & In rubles \\
\hline Number of staff receiving minimum wages & $\begin{array}{l}\text { number of people and } \% \text { of the total number of } \\
\text { employees }\end{array}$ \\
\hline List of positions with the maximum salary & specific profession \\
\hline Maximum wage range & In rubles \\
\hline The number of personnel receiving the maximum wage & $\begin{array}{l}\text { number of people and } \% \text { of the total number of } \\
\text { employees }\end{array}$ \\
\hline Wages structure (elements) & Constant and variable part in $\%$ \\
\hline Dynamics of the Salary of the enterprise for the last 5 years & In rubles and growth rate \\
\hline $\begin{array}{l}\text { Dynamics of the constant part of the Salary for the last } 5 \\
\text { years }\end{array}$ & In rubles and growth rate \\
\hline $\begin{array}{l}\text { Dynamics of the variable part of the Salary for the last } 5 \\
\text { years }\end{array}$ & In rubles and growth rate \\
\hline Productivity & Ruble / person \\
\hline Staff turnover by different categories of posts & In percentages \\
\hline
\end{tabular}

3. Collection of information on the external environment of the enterprise will be a logical continuation of the collection of information on the internal environment. Exemplary indicators of the external environment are presented in Table 4.

Table 4. Information on the external environment

\begin{tabular}{|l|l|}
\hline \multicolumn{1}{|c|}{ indicator } & \multicolumn{1}{|c|}{$\begin{array}{c}\text { Characteristics of the indicator in the } \\
\text { enterprise under study }\end{array}$} \\
\hline Volume of the market, thousand rubles. & Branch, regional (thousand rubles) \\
\hline $\begin{array}{l}\text { Number of enterprises in this market in the region / } \\
\text { city under study }\end{array}$ & Number of main enterprises, total number \\
\hline Market share of the enterprise & $\%$ \\
\hline Average wages in the industry at the national level & In rubles \\
\hline $\begin{array}{l}\text { Average wage in the industry at the regional / city } \\
\text { level }\end{array}$ & In rubles \\
\hline Average salary in the country & In rubles \\
\hline Average salary in the region / city & In rubles \\
\hline $\begin{array}{l}\text { Salary ranges on the market for professions, specific } \\
\text { to the company }\end{array}$ & $\begin{array}{l}\text { Specify the minimum and maximum } \\
\text { wages in rubles }\end{array}$ \\
\hline $\begin{array}{l}\text { Requirements on the labor market for workers in } \\
\text { specific professions, typical for this organization }\end{array}$ & Education, length of service, etc. \\
\hline
\end{tabular}


4. Evaluation of the importance of positions and posts for the company. This stage is designed to identify the most and least important posts for the company. This is necessary to identify key positions that need more attention, because they have a significant impact on the final results of all activities of the enterprise. At this stage, the following RIS principles are implemented: fairness in assessing the labor costs of an employee and his contribution to the final results of an enterprise, taking into account the specifics of the enterprise and the work processes of various groups of employees. It is necessary to carefully monitor the quality of work of employees occupying key positions (workplaces), identify problems inherent in such posts (workplaces) in time and find ways to solve them in time so that workers can work with the required level of return. It is important to reduce both the level of staff turnover on important for the company professions, and the likelihood of professional "burnout" [2] of such employees. The determination of key positions (workplaces) should be made with an orientation to existing production sites in the enterprise. It is necessary to formulate the functions of each department that exists at the enterprise. Each department was formed due to the need to implement specific tasks; therefore, posts are assigned according to the functions of departments, which are really capable of influencing the implementation of assigned tasks. When determining the significance of individual posts within departments, one should resort to the opinion of their leaders. Classification of posts by importance for the organization can be carried out using different methods [3]: paired comparisons, ranking, factor, ball methods, etc. It is necessary to split existing posts into groups carefully, paying attention to all categories of employees. In the fourth stage, such tasks of the RIS [4] are solved, as the determination of employees and positions valuable for the company, the size of the fair remuneration of employees.

5. Development of incentive system based on rationality criteria. This stage provides for the formation of objectives, RIS principles of the enterprise, target indicators. It is necessary to develop the incentive system itself, relying on material, non-material incentives and stimulation of living conditions [5]. In order to develop a rational incentive system, it is necessary to take into account the existing limitations of the company (resource, personnel, information, technical, etc.). The result of this stage is the development of a regulatory document regulating the issues of incentives in the enterprise.

6. Testing. There is an introduction of the RIS to the enterprise. At the same time, it is recommended to implement, if possible, any part of it. It can be one of the units or a branch. The use of a pilot project [6] will identify potential difficulties and significant factors that may affect the outcome of the implementation of the main project. A pilot project can be a very effective solution for innovative and high-tech projects with a high degree of uncertainty in the outcome and ways to achieve it. The recommended duration of the pilot project is at least 6 months, after this term it is possible to make a transition to a wider application of the RIS in the enterprise.

7. Finalization. The testing phase will reveal the positive and negative aspects of the RIS developed for the enterprise. Accordingly, the RIS may undergo certain changes at the stage of completion.

8. Evaluation of the effectiveness of the incentive system. The final stage of the algorithm for the formation of a rational incentive system at the enterprise is to evaluate the results of its implementation. When developing the incentive system by criteria of rationality, the target indicators were formed for a certain period. The long-term, mediumterm or short-term objectives were made, respectively, the evaluation of the current incentive system should be carried out for specified periods. We recommend that you evaluate at least once a year. If the incentive system does not allow to achieve the set goals (the indicators are not met or partially implemented), then it is necessary to return to the initial stage of the algorithm for the formation of a rational incentive system at the enterprise. 


\section{Conclusion}

In the real world, there are no absolutely identical organizations, so it is difficult to answer the question about the possibility of developing a universal rational incentive system (RIS) unequivocally. An incentive system that works effectively in one organization may not be effective at another enterprise at all. And no matter how analysis justify this state of affairs, it is essential for the enterprise to obtain results for the current / planned time period. Therefore, it is especially important that the algorithm for the formation of a rational incentive system can be adapted to the largest possible number of enterprises, despite the variety of activities, the difference in the number of personnel, the length of time in the market and other factors.

Thus, the algorithm for the formation of the RIS provides for eight stages, is universal, it is possible to use it in enterprises of various industries, including transport companies. The most important stage is the evaluation of the effectiveness of the incentive system. If the incentive system does not allow achieving the set goals (the indicators are not met or partially implemented), then it is necessary to return to the initial stages of the algorithm.

\section{References}

1. A.V. Kopytova, Exchange of intellectual property 3 (XIV), 31-37 (2015)

2. V. Lezier, M. Gusarova, A. Kopytova, IOP Conference Series: Earth and Environmental Science, 90 (1), 012069 (2017) DOI: 10.1088/1755-1315/90/1/012069

3. N. Zotkina, M. Gusarova, A. Kopytova, Advances in Intelligent Systems and Computing 692, 1204-1213 (2018) DOI: 10.1007/978-3-319-70987-1_129

4. V. Lezier, M. Gusarova, A. Kopytova, IOP Conference Series: Earth and Environmental Science, 90 (1), 012034 (2017) DOI: 10.1088/1755-1315/90/1/012034

5. N. Zotkina, A. Kopytova, M. Zenkina, O. Zhigunova, MATEC Web of Conferences, 106, 08058 (2017) DOI: 10.1051/matecconf/201710608058
6. A. Kopytova, Procedia 10.1016/j.proeng.2016.11.830
Engineering
165, 1132
(2016)
DOI: 